\title{
THE RELIGIOUS CONCEPTS OF BONES IN TEXTS OF EDFU TEMPLE
}

\author{
Mohammed A. ELSAYED \\ Fayoum University, Egypt \\ mas02@fayoum.edu.eg
}

\begin{abstract}
This paper focuses on the multifaceted concepts of bones in texts of Edfu temple. Many religious concepts refer to this issue such as the triumph over the forces of chaos, the legend of Osiris in which his two sisters collected his limbs and bones together, and the myth of Khnum who creates the semen from bones.
\end{abstract}

تتتاول هذه الورقة البحثية الأفكار الدينية

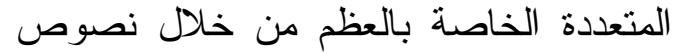

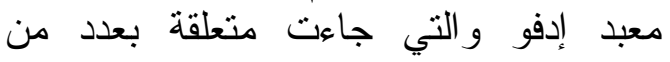

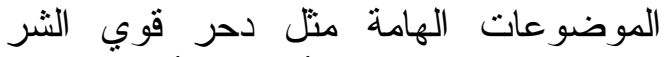
بالمعبد ، كذلك في ثنايا أسطورة أوزير و الني

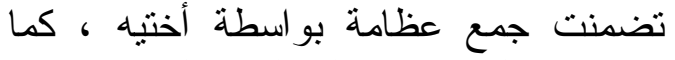

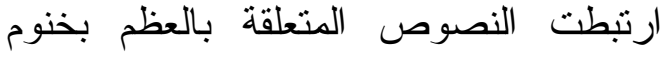
الخالق الذي يضع السائل المنوي في العظم.

\section{KEYWORDS}

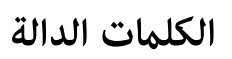

Bones; Edfu Temple; Horus of Behedty; Legend of Osiris; Triumph over the forces

$$
\text { أوزير، التغلب معبد إدفو، حورس الإدفوي، أسطورة الثر. }
$$
of chaos.

\section{INTRODUCTION $^{1}$}

At Edfu, four different terms refer to bones $3 h 3 h$ $t_{s t}{ }^{\infty} 111.5$ Through the contexts of their usage, it becomes clear that nuances exist among these terms to distinguish them. The first two terms $3 h \underline{h} h$ and $h \underline{d}$ are linked with the

\footnotetext{
${ }^{1} \mathrm{I}$ wish to express my gratitude to Mr. D. Jones for his careful reading and for his many useful corrections and insightful comments.

${ }^{2}$ Wilson, Ptol. Lexikon, 20-21.

${ }^{3}$ Wilson, Ptol. Lexikon, 696.

${ }^{4}$ Wilson, Ptol. Lexikon, 1069.

${ }^{5}$ Wilson, Ptol. Lexikon, 1175. The survey of these words is based on Wilson, Ptol. Lexikon. The difference is used for several purposes such as punning and paronomasia or wordplay to increase the magical potency of texts.
} 
resurrection and regeneration of Osiris; ${ }^{1} 3 h \underline{h}$ means "be verdant" while $h \underline{d}$ is "white" or "silver" ${ }^{\prime \prime}$ in reference to the rejuvenation of the bones of Osiris. The other two words are linked with prototypical enemies. ${ }^{3} K s$ usually refers to the bones of the hippopotamus or that of a foe while tst is the backbone of a foe which has been chopped by the king.

A broad spectrum of texts is related. They differed between the triumph over the forces of chaos ${ }^{4}$ and the hymens stating that the body of Osiris was revived by his two sisters when they collected the bones of his mummy. Khnum of Esna as a creator god increases the semen from the bones. ${ }^{5}$ The protective qualities of an amulet dedicated to the protection of the bones of the reigning pharaoh are emphasised. Also, the relevant texts in the daily rituals point to the king who purifies the head of the god and makes divine his bones with the ointment and water vessels.

The offerings rituals, including the above concepts, are categorised as:

A) Killing the turtle ${ }^{6}$ or casting the sharp harpoon at the hippopotamus. ${ }^{7}$

B) Burning the bones and flesh of Seth in the Red Mountain in the texts of the Twenty-second nome, as part of the Procession of Hapi. ${ }^{8}$ The bones of the forces of chaos are destroyed by putting them in a fiery brazier. ${ }^{9}$

C) Pouring water ${ }^{10}$ and providing $m \underline{d}$-ointment ${ }^{11}$ where the priest or the king purifies the head and bones of the main deity during the daily rituals.

D) In the hymns praising Horus of Behedty reflecting his triumph over his prototypical enemies. ${ }^{12}$

E) Texts linked to Mehyt ${ }^{13}$ who rejuvenates bones. ${ }^{14}$

F) All the hymnic material which invokes Osiris as an indication of triumphant resurrection and regeneration after death thanks to the collection of his bones by his sisters. ${ }^{15}$

\footnotetext{
${ }^{1}$ Edfou, II, 22 (12), 286 (1); VII, 202 ( 13-14); II, 212 (17), 213 (1).

${ }^{2}$ At Dendera temple, Isis is said to have bones of white gold and flesh of real gold /electrum, Wilson, Ptol. Lexikon, 696.

${ }^{3}$ Edfou, II, 74 (7); IV, 273 (11); V, 27 (7); VII, 159 (6); VI, 66 (1); VI, 70 (1).

${ }^{4}$ This meaning is usually linked to the triumph of Horus over his enemies. Gardiner, JEA 30 (1944), 23-60; Fairman., JEA 30 (1944b), 5-22.

${ }^{5}$ For more on this topic, Sauneron., BIFAO 60 (1960), 19-27; Manniche L., Sexual Life in Ancient Egypt, 1987; Morenz, Egyptian Religion. Trans. A. E. Keep, Ithaca, 1973, 183-184; See the same meaning in Edfou, I, 391, 2; 548, 6.

${ }^{6}$ Edfou, II, 74 (7). As the aspect of Seth, Cruz-Uribe, JARCE 45 (2009), 208.

${ }^{7}$ Edfou, III, 188 (8); II, 45 (5). One of the most common traditions during the Festival of Victory, Gaudard, F.,The Demotic Drama of Horus and Seth. Chicago: The University of Chicago, 2005; Simpson, W. K. (ed.), The Literature of Ancient Egypt, 117-8; Morgan, The Bull of Ombos: Seth \& Egyptian Magic, 309.

${ }^{8}$ Edfou, V, 27 (7); IV, 39 (1).

${ }^{9}$ Edfou, I, 313 (18-19); IV, 2173 (11).

${ }^{10}$ Edfou, II, 213; V II, 53; 202 (13-14).

${ }^{11}$ Edfou, V, 185 (1).

${ }^{12}$ Edfou, I, 381; VI, 70; 66.

${ }^{13}$ A goddess can be assimilated with Isis and Hathor on the uraeus, see $L G G$, III, 371 .

${ }^{14}$ Edfou, II, 212 (17); 213 (1).

${ }^{15}$ Edfou, I, 221.
} 


\section{The contexts of bones in texts of Edfu Temple}

\section{A. The destruction of the enemies}

The enemies' bones were broken and smashed by furious demons, ${ }^{1}$ the king, Horus of Behedty, Amun-Re, Mehyt, the gargoyle lions, ${ }^{2}$ and Wenhedj.

\section{By furious demons ${ }^{3}$}

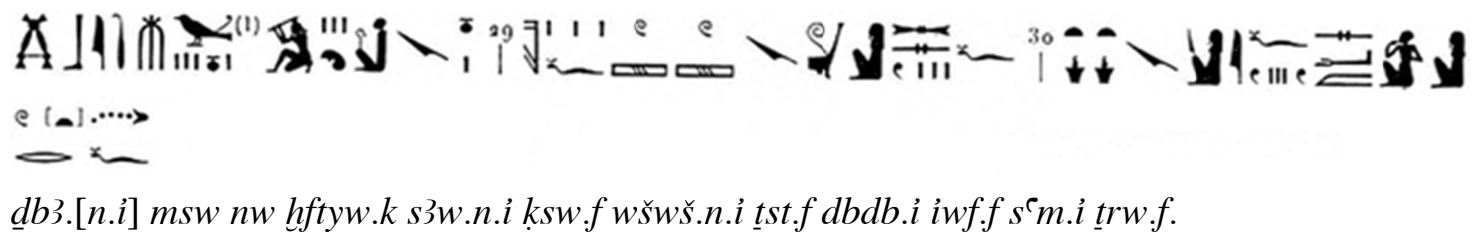

[I] punish the children of your enemies, I break his bones, I smash his vertebrae, I cut up his flesh and I drink his blood. ${ }^{4}$

\section{By the king}

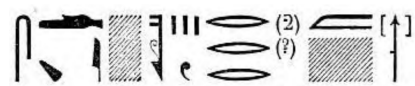

$s d[. i] k s w$. firw m ${ }^{\complement} b b$

[I] break all his bones with the harpoon. ${ }^{5}$

\section{P月⿺}

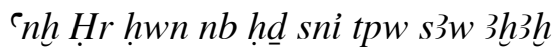

May Horus live, the child, lord of mace, who cuts off the heads and breaks the bones. ${ }^{6}$

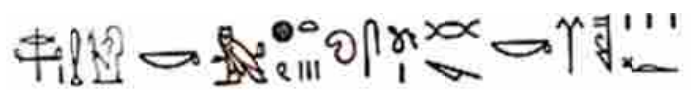

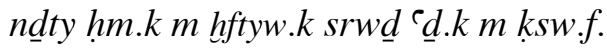

Take your revenge from your enemies, make firm your knife in his bones. ${ }^{7}$

\footnotetext{
${ }^{1}$ The most fully-documented study on this topic is Goyon J. \& Gardiner, A., Les Dieux-Gardiens et la Genèse des Temples, $B d E$ 92, Cairo 1985; for further discussion, Lucarelli, R., Demons, benevolent and malevolent, UEE, 2010. Id, Demonology during the Late Pharaonic and Greco-Roman Periods in Egypt, JANER 11 (2011), 121-124.

${ }^{2}$ See de Wit., CdE 29 (1954), 29-45; de Wit, C., Le rôle et le sens du lion dans l'Égypte ancienne, Leiden, 1951, 127-129.

${ }^{3}$ The name of this protective guardian on the bark of Re is $m 3^{c}-h r$, see $L G G$, III, 215.

${ }^{4}$ Edfou, VI, 66 (1). This sentence can also be seen in Faulkner, The Ancient Egyptian Coffin Texts, I, 106.

${ }^{5}$ Edfou, VII, 159 (6).

${ }^{6}$ Edfou, I, 559 (3).

${ }^{7}$ Edfou, II, 74 (7).
} 


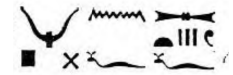

Wp n.f tst.f

He has opened his bones. ${ }^{1}$

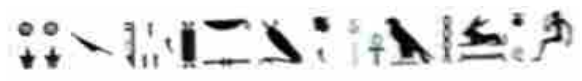

hbhb ksw n ksm.f enh Hr hwwn

Who chops up the bones of his assailant, may Horus live, the child. ${ }^{2}$

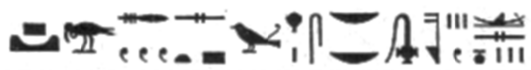

$\underline{d} w d \check{s} r t \underline{h r} h^{\complement} w$ Sth ḥr snb ksw.fim.sn.

The red mountain which contains the flesh of Seth, burning his bones which are in them. ${ }^{3}$

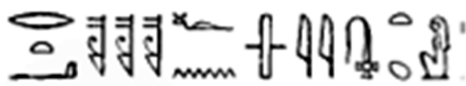

rdit ksw.f n imyt

I give his bones to the fire. ${ }^{4}$

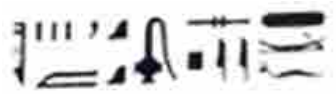

Ksw.fm kk spy im.f

His bones in the fire, he will remain in it. ${ }^{5}$

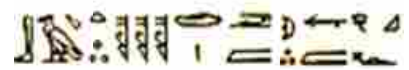

bi3 ksw di.i ${ }^{\top} \mathrm{k} m$ bỉ m msk.f

The cooper harpoon of the bones, I make the harpoon penetrate his leather ${ }^{1}$.

\footnotetext{
${ }^{1}$ Edfou, VI, 70 (1); 72 (4). The sentence refers to the $5^{\text {th }}$ harpoon. The role of the king is similar to Horus who harpoons Seth as a hippopotamus. See Fairman H. W., The Triumph of Horus, 84-100; Watterson, The House of Horus and Edfu: Ritual in an Ancient Egyptian Temple, 115. Lichtheim, Ancient Egyptian Literature: The New Kingdom, 117.

${ }^{2}$ Edfou, IV, 273 (11).

${ }^{3}$ Edfou, V, 27 (7); IV, 39 (11). One spell mentions the mountain where Seth and his confederates were hidden. See Faulkner, The Ancient Egyptian Coffin, 185-188; Lichtheim, Ancient Egyptian Literature, II, 222; Simpson,(ed.), The Literature of Ancient Egypt, 121.

${ }^{4}$ Edfou, I, 381 (6). This sentence is a part of a hymn to Horus of Behdety who rejoices with the burning of the hippopotamus beings.

${ }^{5}$ Edfou, III, 188 (8). This sentence specifically refers to the Hippopotamus form of Seth who is killed by the king.
} 


\section{By Horus of Behdety}

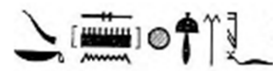

`b.k smnh $m$ ksw.f

your horn hacks his bones. ${ }^{2}$

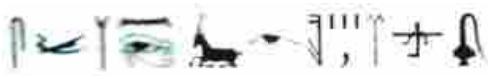

sm3 sbyw $n$ wd 3 t ir ksw.f m sbi

Slay the enemy of the wedjat eye and make his bones in the fire. ${ }^{3}$

\section{By Amun-Re}

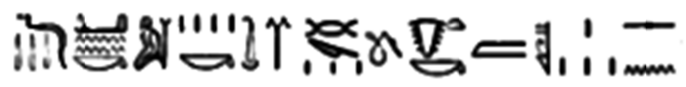

$\underline{d} d m d w$ di $n . k$ sbyw.k mn.ti $m{ }^{\complement} \underline{d} r w \underline{d}{ }^{\complement} \underline{e}$.k $m$ ksw.sn

I give to you your enemies under slaughter; I make your massacre strong in their bones. 4

\section{5. by Mehyt}

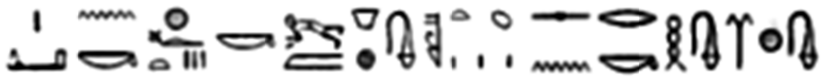

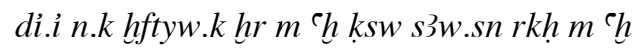

I make your enemies fall down for you in the brazier and make the bones of their sons to burn up in the brazier. ${ }^{5}$

\section{The gargoyle lions}

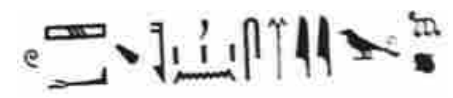

wš $k s w n$ sm3y-nbd

Eating the bones of the Evil One. ${ }^{6}$

${ }^{1}$ Edfou, II, 45 (5).

${ }^{2}$ Edfou, VI, 73 (7). This sentence specifically refers to Seth who is killed by Horus in a bull form.

${ }^{3}$ Edfou, III, 197 (6). This sentence specifically refers to the pig as a form of Seth.

${ }^{4}$ Edfou, I, 83 (18); II, 43 (15).

${ }^{5}$ Edfou, I, 313 (18-19).

${ }^{6}$ Edfou, IV, 111 (6). 


\section{By Wenhedj}

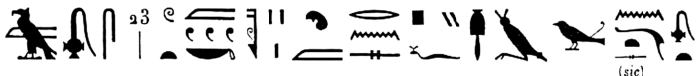

3m.s tw $m$ h'wt.k ksw.k m rn.s pfy mt nsrt

She burns you in your flesh and bones, in her name of Death Fire. ${ }^{1}$

\section{B. Khnum of Esna creates the semen in/from bones ${ }^{2}$}

The creator god, Khnum, attaches semen within the bones of the husbands to make them able to impregnate their wives, thanks to a stronger erection in order to ejaculate the semen within the womb.

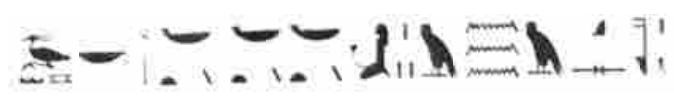

b`h.k idwt m mw m ksw

You inundate the women with semen in the bones. ${ }^{3}$

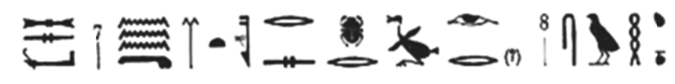

ts $m w$ m ksw r shpr țis ir swht

Who establishes semen in the bones to create children and make egg. ${ }^{4}$

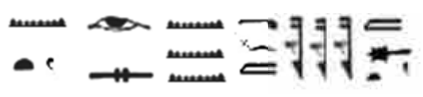

Ntf ir s? mw.fm ksw m $\underline{h t}$

He is the one who creates the semen in the bones in the bodies. ${ }^{5}$

\section{The legend of Osiris}

The following texts assert that the triumphant resurrection and regeneration of Osiris after death are carried out by his two divine sisters Isis and Nephtys, who collected his limbs and bones. ${ }^{6}$ Horus then buried these in Edfu.

${ }^{1}$ Edfou, VI, 159 (14-15).

${ }^{2}$ Sauneron, Blackman and Fairman suggested that $k s w$ means the phallus. See Wilson, Ptol. Lexikon, 1069.

${ }^{3}$ Edfou, IV, 298 (3-4).

${ }_{5}^{4}$ Edfou, V, $185(1)$.

${ }_{6}^{5}$ Edfou, III, 114 (7). For parallel texts, see Esna, II, 200 (10); 356 ( 13); V, 176; 276, 12; V, 159.

${ }^{6}$ For more about their role through the songs which were performed during the Feast of Osiris. Faulkner, The Lamentations of Isis and Nephtys, in Mélanges Maspero, T.1, fasc.1, MIFAO, 66, 34; Hailkal, Two Hieratic Funerary Papyri of Nesmin, part two, translated and commentary, BAe, 52. 


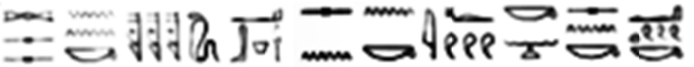

ts.sn ksw.k i`b.sn n.k iwf.k dmd.sn n.k`wt.k

They joined your bones to you, they united your flesh and they joined your limbs. ${ }^{1}$

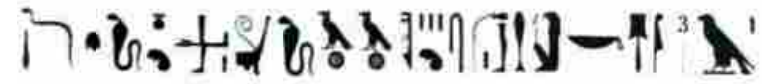

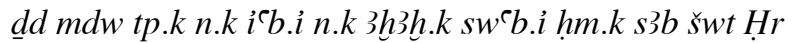

Your head is yours, I unite your bones, I purify your majesty [by] the dappled of feathers, Horus. ${ }^{2}$

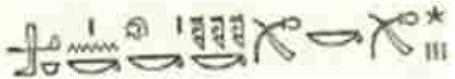

i`b.i n.k tp.k ksw.k ${ }^{\complement} b . k{ }^{\complement} b$ ntrw

I have united for you your head and bones to you, your purification is the gods purification. $^{3}$

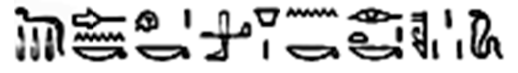

dd $m d w$ mn n.k tp.k i’b.i n.k irt.k ksw.k

I give to you your head, I unite for you your eye and your bones. ${ }^{4}$

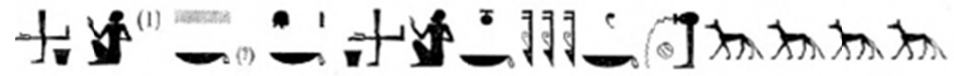

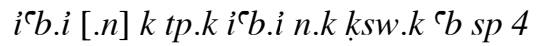

I have united, for you, your head, I have joined for you your bones, the purification is four times. ${ }^{5}$

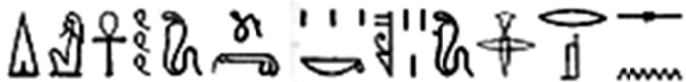

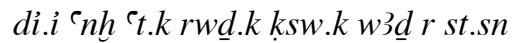

I cause your limbs to live, your sinew and bones strong in their places. ${ }^{6}$

\footnotetext{
${ }^{1}$ Edfou, I, 221 (5). The different ceremonies of Osiris may have happened the month of Khoiak. Chassinat, E., Le Mystère d'Osiris au mois de Khoiak, 90; Gaballa, A. G., Kitchen. K. A., the Festival of Sakar, OR, 38, 1969, 37ff; Daumas, ChoiakFest, LÄ I, 959.

${ }^{2}$ Edfou, III 22 (12). This concept can be traced back to the Pyramid Texts, see Allen, The Ancient Egyptian Pyramid Texts., 87; Faulkner, The Ancient Egyptian Pyramid Texts, 136.

${ }^{3}$ Edfou, I, 170 (13).

${ }^{4}$ Edfou, I, 77 (6).

${ }^{5}$ Edfou,VII, 53 (12-13).

${ }^{6}$ Edfou, I, 371 (17).
} 


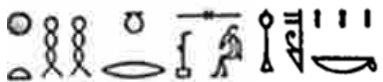

iht-n-ḥh $r$ srnp $h \underline{d} \underline{w} w . k$

the ointment to make your bones young. ${ }^{1}$

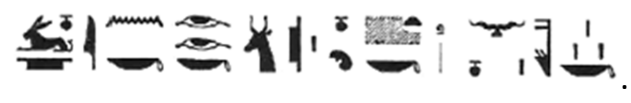

Wn.ỉ n.k irty.k sš.i n.k [..] dmd n.i ksw.k

I open for you your eyes, I open for your [..], I unite your bones. ${ }^{2}$

\section{The daily rituals}

The king as the highest priest in Egypt performs the ordinary daily purification rituals on the bones of the god by using water, ointment, and amulet.

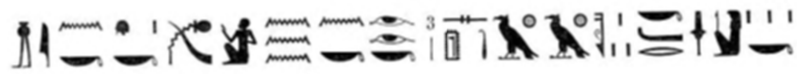

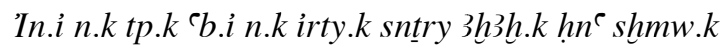

I bring your head to you, I purify your eyes for you and I make divine your bones with your statues. ${ }^{3}$

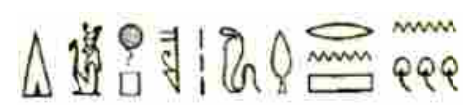

di.i hpr ksw.k im r nšni

I make your bones safe from anger. ${ }^{4}$

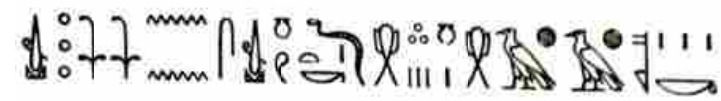

w3 $\underline{d} n n s w 3 \underline{d} n . f \underline{d} t . k s 3 w n s 33 h 3 h . k$

This wadj amulet protects your bones, it is the protection that protects your bones. ${ }^{5}$

\section{Conclusions}

The excerpts of texts mentioned assert that the resurrection of Osiris was carried out by collecting his limbs/bones and together, gave the breath of life to his body. This

\footnotetext{
${ }^{1}$ Edfou, II, 212 (17), 213 (1). At Dendera a statue of Isis is said to have bones of white gold and flesh of real gold / electrum, Dendera, III, 43 (7-8).

${ }^{2}$ Edfou, V, 238 (10); 239 (4).

${ }^{3}$ Edfou, VII, 202 (13-14).

${ }^{4}$ Edfou, I, 36 (6). For comparison, see Faulkner, R.O, The Ancient Egyptian Coffin Texts, I, 285.

${ }^{5}$ Edfou, II, 286,1.
} 
may be a way of decoding the daily rituals performed for the statue of the main deity in order to bring his rejuvenation by water and ointment. This image can be seen when the creator god Khnum bestows semen concentrated in/from bones, to impregnate the womb and create a foetus as a new life.

By contrast, destroying enemies was achieved by breaking, hacking, chopping, and burning their bones. This is understood as Seth burns his bones and flesh in the Red Mountain, where he was buried. However, according to the myth, Seth reconciled with Horus and was not destroyed. ${ }^{1}$

The ritual of harpooning the hippopotamus implies that Seth was easily defeated by the king, who is the heir of Horus with regard to the throne of Egypt. Furthermore, the texts above assert the role of Horus in reuniting the limbs/bones of his father to his head. He joined his bones and purified His Majesty, the same way as Horus buried his father at Edfu.

A vital sentence reflects the god's ability to destroy his enemies' bones with his horns. This indicates the animal shape of the god as a strong ram or bull goring enemies with his horns. This is expressed in many instances: "I gore the one who attacks you with my horns". ${ }^{2}$ Many gods had the title $d m$ hnty meaning "sharp of horns". This evidence suggests interpreting the horns as elements forming parts of the atef crown. It may also be in the form of a cap with horns. In one inscription, Horus of Behdety is described as having "two great plumes united with horns on his brow". 4

Furthermore, the pharaoh was known as "sharp of horns". It is an essential element as it can be traced to the early expression of kingship on the Bull palette dating to the Naqada III period. It shows the reigning pharaoh as the heir of Horus in the form of a bull goring the bones of his defeated enemies.

At Edfu, pouring water was performed to clean and remove the anger from the god's bones. Giving ointment rejuvenated bones of the gods. Furthermore, amulets were offered to protect the bones from risks.

Finally, the texts discussed here initially reflected the struggle between the forces of order represented by Osiris, by Horus of Behdety and by the king (his successor) and the forces of chaos represented by Seth and his cohorts that were believed to threaten the security and stability of the Egyptian cosmos.

\footnotetext{
${ }^{1}$ See Griffith, The Conflict of Horus and Seth, in: Gardiner, Late Egyptian stories, 37-66; Wente, The Conflict of Horus and Seth from Egyptian and Classical Sources by J. Gwyn Griffiths, JNES 22 (1963), 273-276.

${ }^{2}$ Edfou, VI, 178 (10); see the same in Edfou, I 99 (9).

${ }^{3} \mathrm{~Wb}$. V 448 (13).

${ }^{4}$ Edfou, IV, 8 (8).

${ }^{5}$ KRI II, 318, 15 .
}

95 - The Religious Concepts of Bones in Texts of Edfu Temple 


\section{REFERENCES}

1. Allen, J.P, The Ancient Egyptian Pyramid Texts. Atlanta: Society of Biblical Literature, (2005).

2. Chassinat, E., Le mystère d'Osiris au mois de Khoiak, IFAO, Le Caire, (1966).

3. Daumas, F., "Choiak Fest, " $L \ddot{A} \mathrm{I}, 958-959$.

4. de Wit, C., Le rôle et le sens du lion dans l'Égypte ancienne, Leiden, (1951).

5. de Wit, C., "Les inscriptions des lions-gargouilles du temple d'Edfou," CdE 29 (1954), 29-45.

6. Fairman, H. W., The Triumph of Horus, London, (1974).

7. Fair man, H. W., "The Myth of Horus at Edfu: II. C. The Triumph of Horus over his Enemies a Sacred Drama (Concluded)", JEA 30, (1944), 5-22.

8. Faulkner, R. O., The Ancient Egyptian Pyramid Texts. Stilwell: Digireads.com Publishing, (2007).

9. Faulkner, R.O, The Ancient Egyptian Coffin Texts. Warminster: Aris and Phillips, (2004).

10. --------, The Lamentations of Isis and Nephtys, in Mélanges Maspero, T.1, fasc.1, MIFAO, 66, Cairo, IFAO, (1934).

11. Gaballa, A. G. \& Kitchen. K. A., The Festival of Sakar, OR, 38, (1969).

12. Gardiner, A., "Horus the Behdetite", JEA 30, (1944), 23-60

13. Gaudard, F., The Demotic Drama of Horus and Seth. Chicago: The University of Chicago, (2000).

14. Goyon J. \& Gardiner, A. Les dieux-gardiens et la genèse des temples, BdE 92, Cairo, (1985).

15. Haikal, F., Two Hieratic Funerary Papyri of Nesmin, 2 volumes, BAe, 15 (1972).

16. Lichtheim, M., Ancient Egyptian Literature: The New Kingdom. Berkeley: University of California Press, III, (1980).

17. Lucarelli, R., Demonology during the Late Pharaonic and Greco-Roman Periods in Egypt, JANER 11, (2011), 121-124.

18. Lucarelli, R., Demons, (benevolent and malevolent), UEE, (2010).

19. Manniche L., Sexual Life in Ancient Egypt., KPI Ltd: London and New York, (1987).

20. Morenz, S., Egyptian Religion. Trans. A. E. Keep, Ithaca, NY: Cornell University Press, (1973).

21. Morgan, M., The Bull of Ombos: Seth \& Egyptian Magic. Oxford: Mandrake and Mogg Morgan, (2005).

22. Sauneron, S., "Le germe dans les Os", BIFAO 60, (1960), 19-27.

23. Simpson, W. K. (Ed.), The Literature of Ancient Egypt. New Haven: Yale University Press, (1973).

24. Watterson, B., The House of Horus and Edfu: Ritual in an Ancient Egyptian Temple. Stroud: Tempus, (1998).

25. Wilson, P, A Ptolemaic Lexikon, A Lexicographical study of the texts in the temple of Edfou, Leuven, (1997). 